\title{
Biphasic Thiosulphate Utilization by a Marine Thiobacillus
}

\author{
By J. R. MURPHY, J. M. KORNFELD*, AND R. C. TILTON \\ University of Connecticut Health Centre, Hartford, Connecticut o6Ior, U.S.A. \\ (Accepted for publication I7 July I97I)
}

Most reports concerning the oxidation of reduced sulphur compounds have involved the chemolithotrophic micro-organisms of the genus Thiobacillus. Three of these reports (Tilton, Cobet \& Jones, 1967a; Tilton, I968; Adair \& Gunderson, 1969a) were concerned with the distribution, and a fourth (Tilton, Stewart \& Jones, $1967 b$ ) with fine structure of organisms isolated from ocean waters. Adair \& Gunderson (1969 $b$ ) characterized a facultative autotrophic Thiobacillus isolated from the Pacific Ocean. In this communication, the biphasic utilization of thiosulphate by the marine isolate, Thiobacillus sp. IV-85 is described.

\section{METHODS}

A culture of an unknown Thiobacillus, designated Thiobacillus sp. IV-85, was isolated from the Atlantic Ocean according to the procedures of Tilton (I968). The organism was maintained on thiosulphate salts broth of the following composition: $24 \cdot 8 \mathrm{I} \mathrm{g}$. $\mathrm{Na}_{2} \mathrm{~S}_{2} \mathrm{O}_{3} \cdot 5 \mathrm{H}_{2} \mathrm{O}$; 2.20 g. $\mathrm{NH}_{4} \mathrm{Cl} ; 2 \cdot 00$ g. $\mathrm{KH}_{2} \mathrm{PO}_{4} ; 500 \mathrm{ml}$. synthetic sea water (Lyman \& Fleming, 1940); and $500 \mathrm{ml}$. distilled deionized water. The $\mathrm{pH}$ of the medium was adjusted to 5.0 with $5 \mathrm{~N}-\mathrm{HCl}$ and the medium was steam sterilized at $\mathrm{I} 2 \mathrm{I}^{\circ}$ for $\mathrm{I} 5 \mathrm{~min}$. Bacteria were grown in $\mathrm{I} \cdot 0 \mathrm{l}$. cultures at $20^{\circ}$, shaken at $200 \mathrm{rev} . / \mathrm{min}$. Thiosulphate was determined by iodine titration using a starch indicator. Total polythionates were determined according to the method of Starkey (1934). Triplicate plating of suspensions on thiosulphate salts agar gave wide variation in viable count; therefore, total count was determined with a Petroff-Hausser counting chamber.

\section{RESULTS AND DISCUSSION}

Adair \& Gunderson (1969a) reported that at least $50 \%$ sea water was required in their thiosulphate salts broth for the optimal growth of two thiobacilli isolated from the Pacific Ocean. Fig. I shows that the marine isolate Thiobacillus sp. IV-85 grew equally well whether the growth medium was supplemented with or devoid of synthetic sea water. The length of the lag periods in those flasks containing $100,80,60$ and $40 \%$ synthetic sea water were essentially the same. The length of the lag period in those flasks containing $20 \%$ synthetic sea water was slightly longer, whereas the lag period in those flasks devoid of sea water was greatly extended. Fig. I also shows that in all cases, irrespective of the concentration of sea water, thiosulphate utilization during the growth of Thiobacillus sp. IV-85 proceeded in two sequential logarithmic phases. Biphasic utilization of thiosulphate by a Thiobacillus has not hithertofore been reported in the literature. A full log plot of the total count against thiosulphate utilization showed a direct correlation between the disappearance of thiosulphate and growth of the organism.

In $50 \%$ synthetic sea water + thiosulphate salts medium the first logarithmic phase of growth was characterized by an increase in the $\mathrm{pH}$ from $5 \cdot 0$ to $5 \cdot 75$. The concentration of

* Present address: Connecticut State Department of Health, Hartford, Connecticut 06IoI, U.S.A. 
polythionates also increased during the first log phase. The increase in $\mathrm{pH}$ reached a maximum at the time of the transition from the first to the second log phase of growth. During the second logarithmic phase the $\mathrm{pH}$ decreased, reaching 4.7 at the time of complete thiosulphate disappearance. There was then a rapid decrease in the concentration of polythionates and a concomitant decrease in the $\mathrm{pH}$. The final $\mathrm{pH}$ after $72 \mathrm{~h}$. was $2 \cdot 4$. Generation times for the first and second logarithmic phases were 2.8 and $7.6 \mathrm{~h}$. respectively.

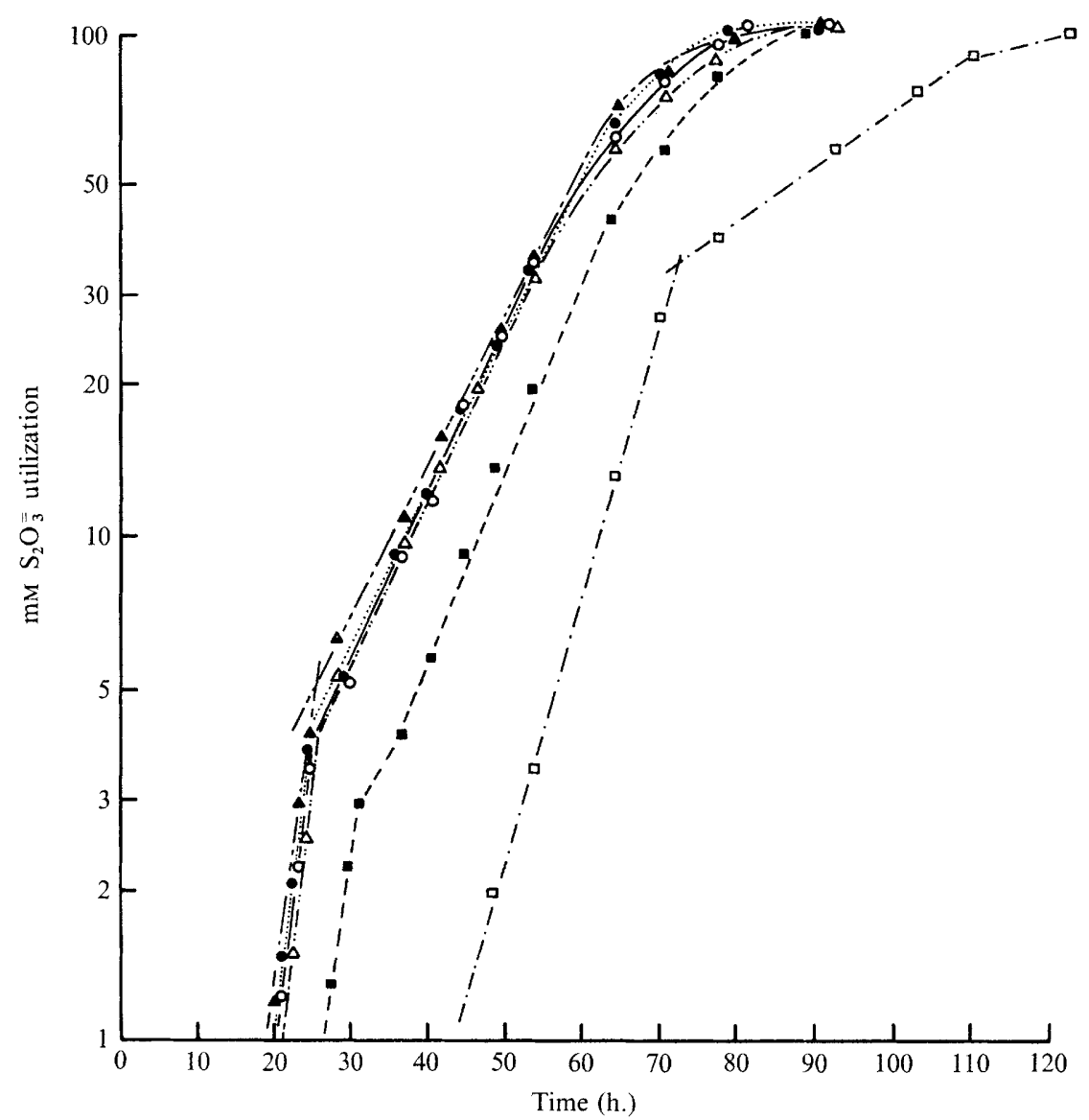

Fig. I. Thiosulphate utilization during growth of Thiobacillus sp. IV- 85 in thiosulphate salts medium supplemented with varying concentrations of sea water: $100 \%, \bullet ; 80 \%, 0 ; 60 \%, \boldsymbol{\Delta} ; 40 \%, \triangle$; $20 \%, \mathbf{\square} ; 0 \%, \square$.

Little is known of the role that marine thiobacilli play in the biogeochemistry of sulphur in the marine environment, and less is known of the physiology of these thiobacilli. Tilton (1967a, 1968) and Adair \& Gunderson (1969b) reported that their isolates were marine counterparts to thiobacilli isolated from terrestrial sources. Results from our laboratory indicate that all terrestrial strains so far examined utilize thiosulphate in a single logarithmic rate during 'log phase' growth.

Since the oxidation of thiosulphate provides the energy and reducing power for growth of the thiobacilli, the abrupt alteration in the rate of thiosulphate oxidation by Thiobacillus $\mathrm{sp}$. IV-85 suggests that one (or more) of the mechanisms of thiosulphate oxidation is inhibited.

This investigation was supported by a National Science Foundation grant, no. 6787. 


\section{REFERENCES}

AdAir, F. W. \& GUNDERSON, K. (1969a). Chemoautotrophic sulphur bacteria in the marine environment. I. Isolation, cultivation, and distribution. Canadian Journal of Microbiology 15, 345-353.

AdAiR, F. W. \& GUNDERson, K. (1969b). Chemoautotrophic sulphur bacteria in the marine environment. II. Characterization of obligately marine facultative autotroph. Canadian Journal of Microbiology I5, 355-359.

Lyman, J. \& Fleming, R. H. (1940). Composition of sea water. Journal of Marine Research 3, 134-I46.

StARKeY, R. L. (1934). The production of polythionates from thiosulphate by micro-organisms. Journal of Bacteriology 28, 287-400.

TILTON, R. C. (1968). The distribution and characterization of marine sulphur bacteria. Revue Internationale D'Océanographie Médicale Tome 9, 237-253.

Tilton, R. C., COBET, H. \& Jones, G. E. (1967a). Significance and distribution of marine sulphur oxidizing bacteria. Canadian Journal of Microbiology I3, I52I-1 528.

Tilton, R. C., Stewart, G. \& Jones, G. E. (1967b). Characterization and ultrastructure of marine sulphur oxidizing bacteria. Canadian Journal of Microbiology 13, I529-1536. 